\title{
ALTERNASI MEDIA DALAM PEMBELAJARAN AL-QUR'AN HADIS PADA MASA PANDEMI COVID-19
}

\author{
KHUSNAINI FAUZI \\ MTs Negeri 2 Temanggung, Jawa Tengah \\ e-mail : beta.unik39@gmail.com
}

\begin{abstract}
ABSTRAK
Tujuan penelitian ini adalah menganalisis media alternatif dalam pembelajaran Al-Qur'an Hadis pada masa pandemi Covid-19. Jenis penelitian ini adalah studi literatur atau penelitian kepustakaan dengan menggunakan sumber data primer dalam bentuk jurnal yang dicari melalui google scholar. Selain itu, didukung oleh sumber data sekunder, yaitu literatur dalam bentuk buku, website dan peraturan pemerintah yang sesuai dengan topik dan tujuan penelitian. Data penelitian ini dianalisis secara deskriptif, yaitu penguraian secara teratur data yang telah diperoleh, kemudian diberikan pemahaman, penjelasan dan kesimpulan. Hasil penelitian ini menunjukkan bahwa pelaksanaan pembelajaran daring pada masa pandemi Covid-19 memiliki banyak kendala yang dialami oleh guru dan siswa. Solusi alternatifnya adalah selama pembelajaran daring guru menggunakan media pembelajaran yang sesuai dengan karakteristik siswa dan materi, sehingga proses kegiatan belajar mengajar secara online menjadi lebih efektif. Hal ini terkait dengan komunikasi dan interaksi, yaitu guru dapat menyampaikan materi pembelajaran kepada siswa secara efisien. Media pembelajaran yang dapat diterapkan guru pada masa pandemi diantaranya adalah WhatsApp Group, PowerPoint, FastStone Capture, YouTube dan Google Form.
\end{abstract}

Kata Kunci: Alternasi Media, Pembelajaran Al-Qur'an Hadis, Pandemi Covid-19

\begin{abstract}
The purpose of this research is to analyze the alternative media in learning Koran and Hadis during the covid 19 pandemic. The type of this reseach is a literature study or a library research with journals from google scholar as the primary data sources. Besides, it is supported by the secondary data sources, literatures in forms of books, websites, and government regulations in accordance with the research topic and purpose. The research data are analyzed descriptively, i.e describing the obtained data systematically, then giving comprehension, explanation, and conclution. The result of this research shows that the implementation of online learning during the covid 19 pandemic has many obstacles for both teachers and students. The alternative solution is using learning media in accordance with materials and students characteristic during online learning, so the process of online teaching and learning activities will be more effective. This is related with communication and interaction, teachers can convey learning materials efficiently for students. During the pandemic period, teachers can apply some learning media such as WhatsApp Group, PowerPoint, FastStone Capture, YouTube and Google Form.
\end{abstract}

Key words: Media Alternation, Learning Koran and Hadis, The Covid 19 Pandemic

\section{PENDAHULUAN}

Pandemi global memberikan dampak yang luar biasa terhadap segala macam aspek kehidupan di seluruh negeri, bahkan dunia. Pengaruh tersebut memberikan kontribusi yang signifikan kepada masyarakat dunia untuk meresponnya dengan merubah mindset dan gaya hidup akibat Covid yang terjadi di akhir tahun 2019. Respon tersebut tentu saja harus mengarah kepada aksi nyata dalam kebiasaan hidup baru yang berubah sebagai solusi alternatif pencegahan untuk meminimalisir penyebaran Corona Virus Disease 19 yang dapat mengancam krisis multidimensi. Krisis terjadi tidak hanya dalam bidang kesehatan, ekonomi, politik, sosial, tetapi juga pada sektor pendidikan yang nota bene adalah sektor vital negeri sebagai wadah dan wahana dalam menyiapkan bekal sumber daya manusia (SDM) anak 
bangsa. Oleh karena itu, sektor pendidikan menjadi salah satu fokus utama anggaran penanganan Covid-19, selain sektor sosial dan kesehatan. Hal ini mengindikasikan bahwa pendidikan terkena dampak yang cukup fatal.

Pemerintah Indonesia melakukan berbagai upaya untuk mencegah penyebaran virus Corona atau severe acute respiratory syndrome corona virius 2 (SARS-Cov-2). Virus ini menyerang sistem pernapasan yang menyebabkan gangguan ringan pada sistem pernapasan, infeksi paru-paru yang berat hingga kepada kematian. Diantara upaya tersebut adalah mengatur secara ketat protokol kesehatan (prokes) dengan menerapkan aturan 3M, yaitu memakai masker, mencuci tangan dengan rajin pada air yang mengalir dan menjaga jarak (social distancing dan physical distancing, bahkan sampai pada lockdown lokal). Dunia pendidikan juga menerapkan prokes versi lockdown tersebut dengan merubah pelaksanaan pembelajaran, dari pembelajaran tatap muka menjadi pembelajaran jarak jauh.

Hal itu dilaksanakan untuk merespon regulasi yang dikeluarkan oleh Kementerian Pendidikan dan Kebudayaan melalui surat edaran Sekretaris Jendral Nomor 15 tahun 2020, yang mengatur tentang pedoman penyelenggaraan belajar dari rumah dalam masa darurat penyebaran Corona Disease 19 (Covid-19). Sampai dengan akhir tahun pelajaran 2019/2020, pandemi belum juga berakhir. Kondisi ini berlanjut sampai tahun pelajaran baru, yaitu 2020/2021 dan saat ini telah menginjak semester genap. Berbagai upaya telah dilakukan oleh pemerintah untuk menjamin keberlangsungan pembelajaran daring, salah satunya adalah dengan cara memberikan bantuan kuota internet kepada siswa. Dengan demikian diharapkan proses belajar mengajar jarak jauh tetap dapat berlangsung, meskipun di lapangan banyak sekali ditemukan kendala (Sutini:2021).

Pembelajaran online merupakan pembelajaran yang dapat memfasilitasi pembelajar belajar lebih luas, lebih banyak dan bervariasi. Melalui fasilitas yang disediakan oleh sistem tersebut, pembelajar dapat belajar kapan dan dimana saja tanpa terbatas oleh jarak, ruang dan waktu (Munir, 2012). Pembelajaran daring atau pembelajaran jarak jauh sendiri bertujuan untuk memenuhi standar pendidikan melalui pemanfaatan teknologi informasi dengan menggunakan perangkat komputer atau gadget yang saling terhubung antara siswa dan guru. Melalui pemanfaatan teknologi tersebut pembelajaran bisa dilaksanakan dengan baik mengingat masyarakat Indonesia saat ini mayoritas sudah menggunakan internet (Astini, 2020). Pada keadaan normal, pembelajaran dilakukan secara tatap muka atau luring (luar jaringan)/offline dimana setiap siswa datang ke sekolah untuk mengikuti proses kegiatan pembelajaran. Sedangkan pada masa pandemi, pembelajaran dilaksanakan dengan jarak jauh atau daring (dalam jaringan)/online dimana siswa berada dirumah untuk mengikuti proses kegiatan pembelajaran atau sering dikenal dengan istilah study from home (SFH) dan atau work from home (WFH). Pembelajaran yang dilakukan di rumah secara daring tentu saja menimbulkan berbagai macam permasalahan yang dihadapi oleh guru sebagai pemberi ilmu dan siswa sebagai penerima ilmu. Oleh karena itu, guru sebagai pemegang kendali harus merespon dan menyikapi persoalan tersebut dengan mengambil langkah-langkah solutif dalam pembelajaran daring. Salah satu solusinya adalah penggunaan dengan memanfaatkan media pembelajaran yang tepat, efektif dan efisien serta sistematis dalam mendukung pembelajaran yang dilakukan dalam masa darurat Covid-19, minimal materi pembelajaran tersampaikan kepada siswa dan terjadi adanya interaksi serta komunikasi antara guru dengan siswa. Meski hal ini tentu saja jauh dari yang namanya ideal dalam proses kegiatan belajar mengajar seperti pada situasi normal.

Media adalah salah satu penunjang dalam proses pembelajaran. Berhasil atau tidaknya pembelajaran sangat ditentukan oleh media yang digunakan (Atsani, 2020). Media pembelajaran adalah segala sesuatu yang dapat digunakan untuk menyalurkan pesan dari guru kepada siswa (ataupun sebaliknya) sehingga dapat merangsang pikiran, perasaan, minat serta perhatian siswa agar proses pembelajaran dapat berlangsung secara efektif. Media pembelajaran merupakan alat, metode dan teknik yang digunakan dalam rangka lebih mengefektifkan komunikasi dalam pembelajaran (Priansa, 2017:130). Basri (2015:187) 
menyatakan bahwa dengan memperhatikan kompleks dan uniknya proses belajar, ketepatan pemilihan media dan metode pembelajaran akan berpengaruh terhadap hasil belajar siswa. Disamping itu, persepsi siswa juga sangat mempengaruhi hasil belajar. Oleh sebab itu, pemilihan media harus memperhatikan kompleksitas dan keunikan proses belajar. Memahami makna persepsi serta faktor-faktor yang berpengaruh terhadap penjelasan persepsi hendaknya diupayakan secara optimal agar proses pembelajaran dapat berlangsung dengan efektif. Untuk maksud tersebut, perlu diadakan pemilihan media yang tepat sehingga dapat menarik perhatian siswa serta memberikan kejelasan objek yang diamatinya dan bahan pembelajaran yang akan diajarkan disesuaikan dengan pengalaman siswa.

Berdasarkan uraian tersebut dapat dikemukakan disini, bahwa media pembelajaran adalah segala sesuatu yang dapat digunakan oleh guru sebagai alat bantu untuk memberikan informasi mengenai materi pembelajaran sehingga dapat diterima oleh siswa secara sistematis, efektif dan efisien. Oleh karena itu dalam penelitian ini, peneliti mencoba menggali dari berbagai macam literatur tentang media yang digunakan dalam pembelajaran jarak jauh yang sesuai dengan media pembelajaran yang diterapkan oleh peneliti dalam mata pelajaran Al-Qur'an Hadis pada masa pandemi Covid-19.

\section{METODE PENELITIAN}

Desain penelitian ini adalah penelitian literatur. Penelitian literatur bertujun untuk mengkaji atau meninjau secara kritis pengetahuan, gagasan atau temuan yang terdapat di dalam tubuh literatur berorientasi akademik (academic-oriented literature), serta merumuskan kontribusi teoritis dan metodologisnya untuk topik tertentu. Adapun sifat dari penelitian ini adalah analisis deskriptif, yaitu penguraian secara teratur data yang telah diperoleh, kemudian diberikan pemahaman dan penjelasan agar dapat dipahami dengan baik oleh pembaca (Cooper dalam Anshori, Muslich, \& Iswati, S., 2009). Pada penelitian ini penulis menelusuri artikel publikasi sebagai sumber data primer dalam bentuk jurnal yang dicari melalui google scholar dengan menggunakan kata kunci yang dipilih, yakni Pemanfaatan media pembelajaran pada masa pandemi Covid-19. Selain itu, didukung oleh sumber data skunder, yaitu literatur dalam bentuk buku, website dan peraturan pemerintah yang sesuai dengan topik dan tujuan penelitian ini. Literatur tersebut disesuaikan dengan media pembelajaran yang diterapkan sekaligus dimanfaatkan langsung oleh peneliti.

\section{HASIL DAN PEMBAHASAN}

Situasi dan kondisi yang tidak normal karena pandemi global mengakibatkan sektor pendidikan pada setiap jenjang menerima efek yang cukup fatal. Pembelajaran jarak jauh membutuhkan perhatian khusus dari seorang guru terkait dengan transfer pengetahuan yang diberikan kepada siswa tentang materi pelajaran yang diampu berdasarkan pada kurikulum darurat yang disusun oleh setiap sekolah yang tertuang dalam kurikulum tingkat satuan pendidikan (KTSP). Kurikulum darurat tersebut tentu sangat berbeda jauh dengan kurikulum pada kondisi normal. Ada beberapa mata pelajaran terpaksa berkurang jumlah jam pembelajarannya karena terkait dengan waktu pembelajaran yang dikurangi sehingga berakibat terhadap pengurangan alokasi waktu dan materi, berbeda dengan saat pembelajaran pada kondisi normal yang ideal. Hal ini tentu saja berpengaruh pada materi pembelajaran yang akan disampaikan kepada siswa, sehingga guru harus mempertimbangkan dan memilih materi pembelajaran yang crucial dan esensial serta aplikatif dalam menyikapi pandemi.

Dalam rangka mendukung physical distancing ditengah pandemi Covid 19 sesuai intruksi presiden untuk tetap di rumah, belajar di rumah, bekerja di rumah, ibadah di rumah. Menteri Pendidikan dan Kebudayaan (Mendikbud) menindak lanjuti kebijakan tersebut melalui surat edaran (SE) Nomor 4 Tahun 2020 tentang pelaksanaan kebijakan pendidikan dalam masa darurat. Dalam hal ini poin 2 yang menyatakan, bahwa proses belajar dari rumah dilaksanakan dengan ketentuan: 1). Belajar dari rumah melalui pembelajaran daring/jarak jauh dilaksanakan untuk memberikan pengalaman belajar yang bermakna bagi siswa, tanpa 
terbebani tuntutan menuntaskan seluruh capaian kurikulum untuk kenaikan kelas maupun kelulusan; 2). Belajar dari rumah dapat difokuskan pada pendidikan kecakapan hidup antara lain mengenai pandemi Covid-19; 3). Aktivitas dan tugas pembelajaran belajar dari rumah dapat bervariasi antar siswa, sesuai minat dan kondisi masing-masing, termasuk mempertimbangkan kesenjangan akses/fasilitas belajar di rumah; 4). Bukti atau produk aktivitas belajar dari rumah diberi umpan balik yang bersifat kualitatif dan berguna dari guru, tanpa diharuskan memberi skor/nilai kuantitatif. Maria Van Kerkhove ahli epidemiologi WHO pada 20 Maret 2020 juga menambahkan "Saat ini, berkat teknologi yang telah maju, dapat tetap terhubung dengan berbagai cara tanpa benar-benar berada dalam ruangan yang sama dengan orang-orang lain secara fisik", dengan demikian proses belajar mengajar tetap bisa dilakukan dengan pemanfaatan teknologi informasi yang ada (Pakpahan \& Fitriyani, 2020).

Hal ini tentu dirasa berat oleh guru dan siswa. Terutama bagi pendidik, dituntut kreatif dalam penyampaian materi melalui media pembelajaran daring. Ini perlu disesuaikan juga dengan jenjang pendidikan dalam kebutuhannya. Dampaknya akan menimbulkan tekanan fisik maupun psikis (mental). Pola pikir yang positif dapat membantu menerapkan media pembelajaran daring, sehingga menghasilkan capaian pembelajaran yang tetap berkualitas. Belajar di rumah dengan menggunakan media daring mengharapkan orang tua sebagai role model dalam pendampingan belajar anak, dihadapi perubahan sikap. Masa pandemi Covid-19 ini bisa dikatakan sebagai sebuah peluang dalam dunia pendidikan, baik pemanfaatan teknologi seiring dengan industri 4.0, maupun orang tua sebagai mentor. Harapannya, pasca pandemi Covid-19 menjadi terbiasa dengan sistem saat ini sebagai budaya pembelajaran dalam pendidikan (Atsani, 2020).

Pembelajaran online perlu dipersiapkan dengan matang. Walaupun pembelajaran pada hakikatnya sama baik untuk konteks tatap muka maupun online. Namun ada aspek-aspek tertentu yang harus diperhatikan ketika melakukan perencanaan untuk pembelajaran online (Belawati, 2020:46). Salah satunya adalah menyiapkan media yang akan diterapkan dalam pembelajaran, tetapi yang penting diketahui adalah media pembelajaran yang diterapkan sesuai dengan konteks dan karakteristik siswa yang disasar. Media yang dipilih akan mempengaruhi pada jenis kegiatan pembelajaran dan tugas-tugas yang akan dirancang dan dituangkan dalam rencana pembelajaran. Menurut Hamalik (1989:12), media pembelajaran adalah alat, metode dan teknik yang digunakan dalam rangka lebih mengefektifkan komunikasi dan interaksi antara guru dan siswa dalam proses pendidikan dan pengajaran di sekolah. Media dalam proses belajar mengajar cenderung diartikan sebagai alat-alat grafis, photografis atau elektronis untuk menangkap, memproses dan menyusun kembali informasi visual dan verbal (Arsyad, 1997:3). Selama pembelajaran daring guru menggunakan media pembelajaaran yang sesuai dengan karakteristik siswa dan materi, sehingga proses kegiatan belajar mengajar secara online menjadi lebih efektif dalam hal komunikasi dan interaksi, yaitu materi pembelajaran dapat tersampaikan kepada siswa dengan efisien. Berikut diuraikan secara rinci media pembelajaran yang digunakan dalam mata pelajaran Al-Qur'an Hadis pada masa pandemi Covid-19.

\section{WhatsApp Group}

Tren penggunaan media sosial (medsos) belakangan ini semakin meningkat. Salah satunya adalah penggunaan aplikasi WhatsApp di Indonesia semakin populer, dimana hingga tahun 2018 saja pengguna WhatsApp tercatat mencapai 124 juta dan terus menunjukkan peningkatan dari tahun-tahun sebelumnya. Melihat dari berbagai fitur yang ditawarkan oleh WhatsApp (WA), grup WhatsApp menjadi fitur yang unik sebagai media untuk berkomunikasi dan bertukar berbagai file antara peserta dalam satu grup (Pustikayasa:2019).

WhatsApp Group (WAG) merupakan media yang mudah, praktis dan efektif untuk menyampaikan materi pembelajaran Al-Qur'an Hadis baik di kelas VIII maupun kelas IX pada kompetensi dasar (KD) yang terkait dengan pengetahuan (KD.3) maupun keterampilan 
(KD.4). Karena hampir semua siswa menggunakan smartphone yang memiliki aplikasi WA dan familiar terhadap aplikasi tersebut. Platform yang didirikan oleh Brian Action dan Jan Koum ini memungkinkan pengguna melakukan komunikasi dan interaksi dengan obrolan online, berbagi file, foto, rekaman suara, video, bahkan sampai pada bertukar pesan tanpa pulsa, karena menggunakan paket data internet. Penggunaaan aplikasi ini dalam pembelajaran dimungkinkan karena pemerintah menjamin keberlangsungan pembelajaran daring dengan cara memberikan bantuan kuota internet kepada siswa pada semua jenjang, sehingga tidak ada alasan lagi bagi guru dan siswa untuk tidak melaksanakan pembelajaran secara daring. Dengan demikian diharapkan proses belajar mengajar jarak jauh ini tetap dapat berlangsung.

Media WhatsApp mempunyai beberapa kelebihan. Adapun beberapa kelebihan dari media WhatsApp, yakni penggunaan yang mudah, praktis, cepat, hemat data internet, dan dapat diakses hanya dengan handphone, memiliki berbagai fitur yang dapat digunakan untuk berkomunikasi mendukung seperti adanya New Group, New Broadcast, WhatsApp Web, Starred Messages and Setting dengan bantuan layanan internet. Pilihan menu grup yang dijadikan tempat berdiskusi guru dengan siswa maupun siswa dengan teman-temannya dalam memecahkan masalah. Contohnya, guru mengirimkan beberapa soal yang harus dipecahkan sesuai materi yang telah diberikan, berdiskusi, penyampaian materi oleh guru, contohnya dalam pelaksanaan pembelajaran guru dapat menyampaikan materi dengan cara mengirimkan video pengajaran, dengan bentuk foto maupun rekaman suara. Penggunaan WhatsApp sangat membantu kegiatan berkomunikasi dalam pembelajaran jarak jauh di tengah kondisi saat ini (Sidiq:2019).

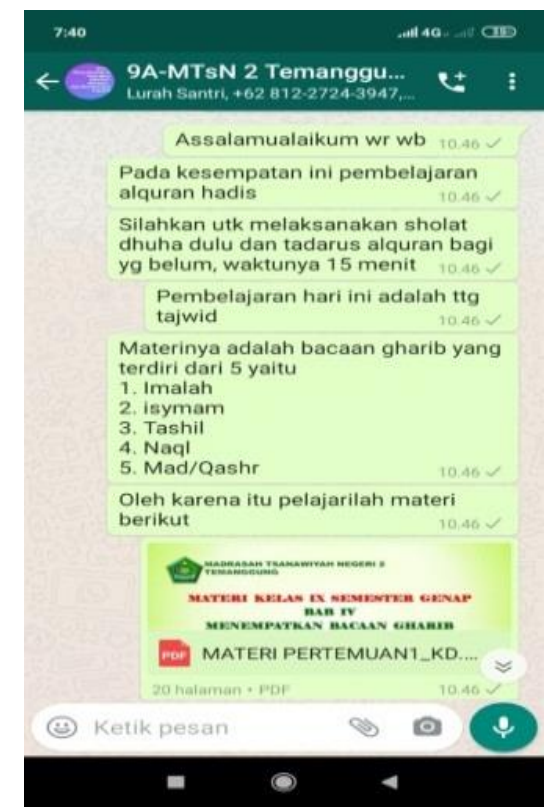

Gambar 1. WhatsApp Group Kelas IX A dalam Pembelajaran Jarak Jauh

Guru memungkinkan membuat WAG yang dapat digunakan sebagai kelas maya atau virtual untuk mengkondisikan proses belajar mengajar. Segala kegiatan pembelajaran terpantau di grup, mulai dari persiapan, pelaksanaan, bahkan sampai pada evaluasi atau penilaian. Konten chat group di WA dapat digunakan untuk integrasi antara guru dengan siswa yang berlangsung dalam waktu nyata (Prajana, 2017). Kegiatan persiapan digunakan untuk mengkondisikan kesiapan siswa ketika akan mengikuti pembelajaran terkait dengan segala sesuatu yang dibutuhkan dalam pembelajaran, seperti informasi kurikulum darurat yang berhubungan dengan materi pembelajaran dan jadwal pelajaran yang di-share oleh wali kelas sehingga sebelum pembelajaran, siswa sudah siap betul untuk mengikutinya.

Guru melaksanakan pembelajaran secara virtual sesuai dengan jadwal dan seolah-olah seperti di kelas tatap muka dengan menulis pesan atau rekaman suara di WAG kelas yang dimulai dengan kegiatan pendahuluan yang mencakup salam, doa, presensi, motivasi dan 
apersepsi. Setelah itu guru melaksanakan kegiatan inti terkait dengan materi esensi pembelajaran yang diberikan kepada siswa dengan membagikan materi dalam bentuk file, seperti $e$-book, pdf powerpoint, dan video offline. Selain itu guru juga dapat membagikan link video pembelajaran yang sudah ter-upload di channel YouTube yang dimiliki oleh guru dan atau menggunakan channel lain selama materinya sama dengan materi pembelajaran yang sedang diajarkan kepada siswa. Setelah kegiatan inti, guru melakukan kegiatan penutup dalam pembelajaran dengan bersama-sama siswa menyimpulkan materi yang baru saja dipelajari, kemudian guru memberikan tugas kepada siswa dan menutup pembelajaran dengan doa dan salam.

Tugas yang diberikan kepada siswa tidak selalu dalam bentuk tugas yang harus dikumpulkan secara online, akan tetapi tugas diberikan dengan tujuan agar siswa dapat menindaklanjuti kegiatan pembelajaran online secara mandiri terkait dengan materi yang telah diberikan oleh guru. Jika terdapat permasalahan, maka siswa dapat bertanya di chat WAG, meskipun diluar jam jadwal pelajaran. Guru memberikan umpan balik dengan mengulang kembali materi yang telah disampaikan sebagai sarana untuk membentuk pemahaman siswa. Hal ini berarti WAG juga berfungsi sebagai ruang diskusi maya antara guru dengan siswa untuk menyelesaikan permasalahan dalam pembelajaran. Interaksi tetap berlangsung sampai pada kegiatan evaluasi atau penilaian yang terkait dengan materi pembelajaran. Bahkan sampai berhubungan dengan apa saja, terlebih tentang update informasi sekolah. Terjadinya komunikasi, interaksi dan diskusi ini menjadi tujuan utama penggunaaan WAG sebagai salah satu media pembelajaran pada masa pandemi Covid-19.

\section{PowerPoint}

Microsoft PowerPoint merupakan salah satu program berbasis multimedia. Software ini menyediakan fasilitas dalam bentuk slide-slide yang dapat membantu dalam menyusun suatu presentasi yang efektif, profesional, dan juga mudah, sehingga memungkinkan para guru di sekolah untuk memanfaatkan sebagai media pembelajaran (Azhar, 2017:16). Mulyawan dalam Maryatun (2015) menyatakan bahwa Microsoft PowerPoint adalah salah satu jenis program komputer yang tergabung dalam Microsoft Office yang digunakan untuk presentasi dan merupakan program berbasis multimedia. Misbahudin dalam Hikmah (2020) menjelaskan, bahwa perlu untuk diketahui bahwa PowerPoint memilki banyak fitur-fitur yang menarik seperti kemampuan pengolah teks, dapat menyisipkan gambar, audio, animasi, efek yang dapat diatur sesuai selera penggunanya, sehingga siswa akan tertarik pada apa yang ditampilkan pada PowerPoint. Selain itu, pembelajaran menggunakan media PowerPoint lebih mudah diakses dan praktis karena tidak memerlukan koneksi internet ketika akan membukanya serta ukuran file yang kecil sehingga tidak memerlukan ruang penyimpanan yang besar (Purwanti, Widyaningrum \& Melinda, 2020).

Pada pembelajaran di masa pandemi Covid 19 diimplementasikan pembelajaran jarak jauh atau daring. PowerPoint merupakan sebuah program komputer untuk presentasi yang dapat dikembangkan guru sebagai sebuah media alternatif dalam pembelajaran yang dilakukan secara online. Software yang sederhana dan mudah dipelajari ini memungkinkan guru membuat materi pembelajaran Al-Qur'an Hadis dalam waktu yang relatif singkat. Materi pembelajaran dalam bentuk presentasi yang terdiri dari beberapa slide yang di desain dengan menarik, materi yang ringkas berisi poin-poin materi sehingga memberikan kesan mendalam kepada siswa dan meningkatkan perhatian lebih kepada materi yang disampaikan guru. Timbulnya persepsi ini merupakan harapan besar bagi guru, bahwa materi yang disampaikan dapat ditindaklanjuti siswa dengan mempelajari dan memahaminya.

Materi yang dibuat dalam bentuk presentasi di software PowerPoint bisa dibuat dalam bentuk file pdf untuk mempermudah dalam pertukaran dokumen secara digital. Jika dalam bentuk file pdf, materi pembelajaran yang telah dibuat guru sudah ter-protect dan bisa langsung di share di WAG sebagai kelas maya untuk setiap KD, baik KD.3 maupun KD.4, yaitu materi Al-Qur'an kelas VIII pada KD. 3.2 tentang menganalisis isi kandungan Q.S. Al- 
Fajr (89) : 15-18 dan Q.S. Al-Baqarah (2) : 254 dan 261 tentang infak di jalan Allah Swt. Siswa dapat merespon file tersebut, jika di smartphone-nya sudah menginstal aplikasi WPS yang bisa didownload melalui fitur playstore. Hal ini akan memudahkan siswa dalam mendapatkan file materi pembelajaran sekaligus mempelajarinya. Materi pembelajaran dalam PowerPoint, kalimatnya dibuat ringkas, singkat, padat dan tepat yang didukung oleh gambar dan beraneka ragam warna yang secara visual dapat menarik perhatian dan menimbulkan kesan mendalam bagi siswa.

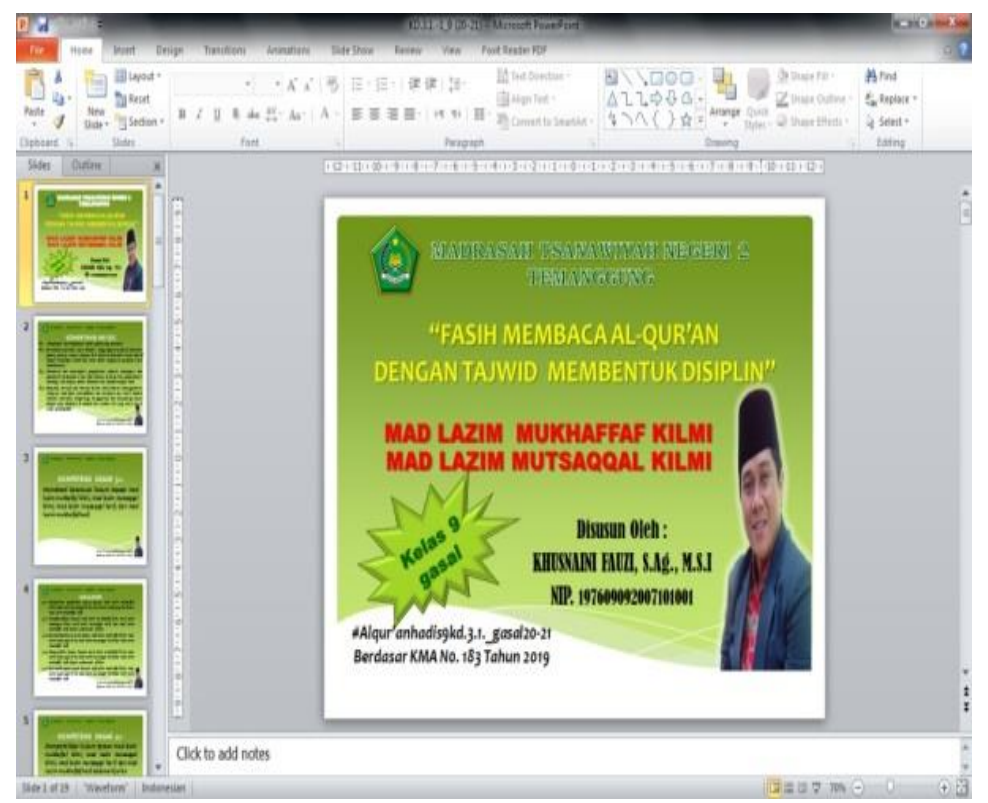

\section{Gambar 2. Materi Tajwid yang Dibuat dalam Bentuk Media Power Point}

\section{FastStone Capture}

Aplikasi lain yang tidak kalah pentingnya adalah perekam layar monitor. Aplikasi ini bermanfaat jika seorang guru ingin merekam aktivitas di layar monitor, untuk memperlihatkan kepada siswa yang umumnya berkenaan dengan bagaimana memanfaatkan atau mempraktikkan materi pembelajaran. Beberapa aplikasi yang dapat digunakan misalnya adalah FastStone Capture atau Movavi Video Editor. Guru dapat menggunakannya sambil merekam suara di aplikasi ini. Keunggulan aplikasi FastStone Capture tidak hanya untuk membuat video rekaman aktivitas di layar monitor, tapi juga dapat menangkap layar di monitor dan disimpan dalam bentuk file gambar (Isroqmi, 2020).

Pada masa pandemi penggunaan media dalam bentuk video pembelajaran sederhana screen recorder merupakan alat pelajaran yang digunakan untuk memberikan pemahaman yang mendalam, karena siswa dapat melihat dan mendengarkan secara langsung materi pembelajaran yang diberikan oleh guru, sehingga materi dapat dipahami baik dari segi teoritik maupun praktik. Alat pelajaran ini dibuat dari sebuah aplikasi screen recorder yang bernama FastStone Capture. Aplikasi sederhana ini memudahkan guru membuat video pembelajaran dengan screen recorder (perekam layar), sehingga materi pembelajaran dapat tersampaikan secara langsung melalui video pembelajaran meski dilakukan dalam PJJ atau daring. Selain itu, video pembelajaran ini digunakan sebagai pengganti pertemuan langsung secara tatap muka karena situasi dan kondisi pandemi Covid-19. Alat ini dapat digunakan menjadi alat bantu pelajaran yang efektif dan efisien selama pandemi. 


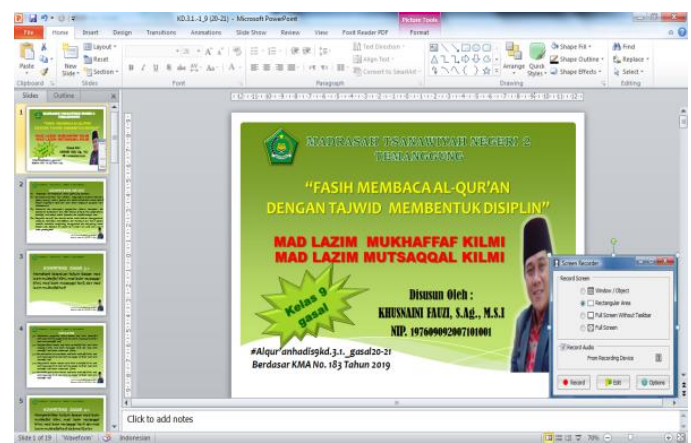

\section{Gambar 3. Proses Perekaman Menggunakan FastStone}

Video pembelajaran FastStone ini digunakan dalam materi tajwid adalah media pembelajaran yang dibuat pada kompetensi dasar memahami ketentuan hukum bacaan mad lazim mukhaffaf kilmi, mad lazim mutsaqqal kilmi, mad lazim mukhaffaf harfi dan mad lazim mutsaqqal harfi. Tujuan dari penggunaan video pembelajaran ini adalah untuk menjelaskan materi tajwid yang ada di kelas IX semester gasal berdasarkan KMA RI No. I83 tahun 2019 tentang Kurikulum Pendidikan Agama Islam (PAI) dan Bahasa Arab. Video yang digunakan sebagai pengantar pembelajaran dalam penyampaian materi untuk menanamkan konsep atau teori tajwid ketika masa pandemi Covid-19. Video ini sebagai pengganti pembelajaran tatap muka secara langsung dengan siswa, sehinggga diharapkan dengan video pembelajaran ini siswa dapat mempelajari materi secara langsung seolah-olah berhadapan dengan guru meskipun pembelajaran dilaksanakan dengan daring, sehingga antusias siswa untuk mengikuti pembelajaran menjadi meningkat yang dapat mempengaruhi motivasi dan hasil belajar siswa.

\section{YouTube}

Salah satu media yang menunjang pembelajaran yang berbasis pada internet yang dapat memvisualisasikan teknik dan materi pembelajaran yang baik adalah YouTube (Sari, 2020). Media ini dapat digunakan sebagai literasi rujukan pembelajaran siswa, sehingga memberikan pemahaman tidak hanya sebagai media hiburan belaka akan tetapi dapat dimanfaatkan untuk menambah pengetahuan dan membuka wawasan keilmuan tentang apa saja yang dapat memberikan inspirasi sebagai motivasi diri (Fauzi, 2020:118). YouTube adalah layanan video sharing populer dimana para penggunanya dapat memuat, menonton dan berbagi klip video secara gratis. YouTube menjadi salah satu media sosial yang praktis dan mudah diakses. Media sosial menjadi alat pengajaran penting untuk menyebarkan informasi kepada siswa dan yang lainnya (Green \& Hope, 2020). Penggunaan video interaktif seperti YouTube ke dalam proses pembelajaran akan meningkatkan keterampilan siswa (Burnett dan Melisa dalam Wijanarko, 2017). YouTube dapat menjadi alternatif untuk mempelajari keterampilan berbasis video, sebagai alat pengajaran untuk menciptakan pengalaman belajar yang aktif antar kelompok siswa dalam rangka peningkatan pengetahuan (Carpenter, et.al., 2008 dalam Suryaman, 2015).

Penggunaan media YouTube ini dalam pembelajaran Al-Qur'an Hadis dalam materi tajwid dan Al-Qur'an di kelas VIII dan IX MTs Negeri 2 Temanggung. Materi tajwid kelas VIII pada kompetensi dasar (KD) 3.1, yaitu memahami ketentuan hukum bacaan mad iwadh, mad layyin dan mad aridh lissukun dan KD. 4.1, yaitu mempraktekkan hukum bacaan mad iwadh, mad layyin dan mad aridh lissukun dalam Al-Qur'an surat pendek pilihan. Materi tajwid ini dibuat dengan menggunakan program komputer untuk presentasi, yaitu Microsoft Office PowerPoint kemudian dibuat video pembelajaran dengan menggunakan Microsoft 365 dalam MS teams dan aplikasi FastStone yang di-upload di channel Youtube peneliti, yaitu khaskhus.channel. Materi tajwid dibuat dalam tiga video pembelajaran yang semuanya diupload di YouTube. Video pertama dengan materi mad iwadh dan mad layyin yang di-upload pada hari Jumat tanggal 24 Juli 2020, video kedua dengan materi mad aridh lissukun yang diupload pada hari Selasa tanggal 4 Agustus 2020. Video tiga dengan materi praktik tajwid 
yang di-upload pada hari Minggu tanggal 9 Agustus 2020. Hasil menunjukkan bahwa siswa yang merespon pada video pertama sejumlah 253 siswa, video kedua sejumlah 156 siswa, dan video 3 sejumlah 258 siswa. Hal ini mengindikasikan bahwa YouTube merupakan media hiburan yang dapat digunakan sebagai salah satu media alternatif pembelajaran yang menarik perhatian siswa sehingga dapat meningkatkan motivasi diri dalam mempelajari materi yang diberikan guru.

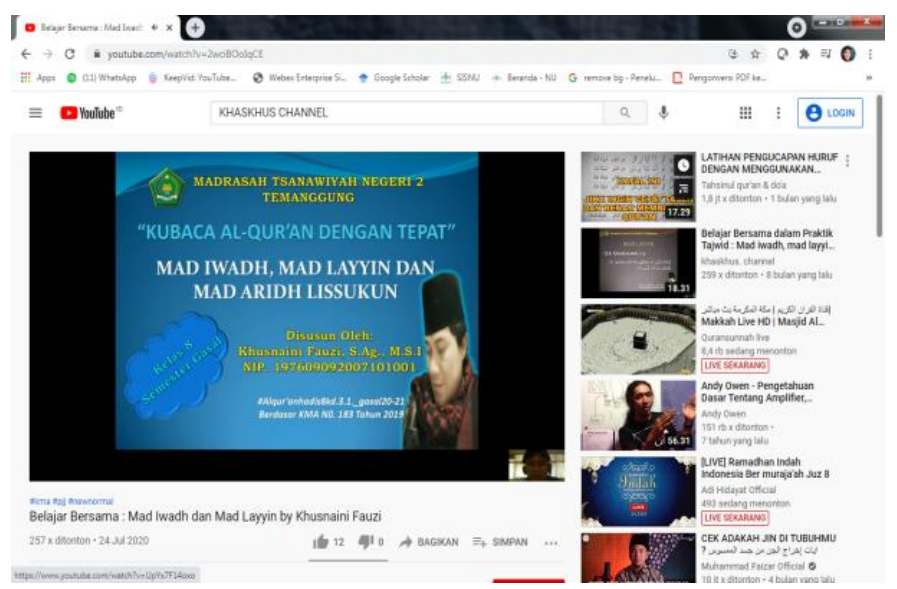

Gambar 4. Materi Tajwid kelas VIII yang Di-upload di YouTube

Selain itu YouTube juga digunakan dalam pembelajaran Al-Qur'an Hadis kelas IX pada materi tajwid KD. 3.1, yaitu memahami ketentuan hukum bacaan mad lazim mukhaffaf kilmi, mad lazim mutsaqqal kilmi, mad lazim mukhaffaf harfi mad lazim mutsaqqal harfi dan KD. 4.1., yaitu mempraktikkan hukum bacaan mad lazim mukhaffaf kilmi, mad lazim mutsaqqal kilmi, mad lazim mukhaffaf harfi dan mad lazim mutsaqqal harfi dalam Al-Qur'an. Materi tajwid ini dibuat dengan menggunakan program komputer untuk presentasi, yaitu Microsoft Office PowerPoint kemudian dibuat video pembelajaran dengan menggunakan Microsoft 365 dalam MS teams dan aplikasi FastStone yang di-upload di channel Youtube penulis. Materi tajwid dibuat dalam tiga video pembelajaran yang semuanya di upload di YouTube. Video pertama dengan materi mad lazim mukhaffaf kilmi dan mad lazim mutsaqqal kilmi yang di-upload pada hari Kamis tanggal 23 Juli 2020 dengan durasi 22 menit 23 detik, video kedua dengan materi mad lazim mukhaffaf harfi dan mad lazim mutsaqqal harfi yang di-upload pada hari Selasa tanggal 4 Agustus 2020 dengan durasi 18 menit 48 detik. Video tiga dengan materi praktik tajwid yang di-upload pada hari Minggu tanggal 9 Agustus 2020. Hasil menunjukkan bahwa siswa yang merespon pada video pertama sejumlah 282 siswa, video kedua sejumlah 280 siswa, dan video 3 sejumlah 362 siswa. YouTube memberikan suasana yang berbeda ketika siswa belajar dengan visualisasi yang menarik, ditambah dengan efek suara.

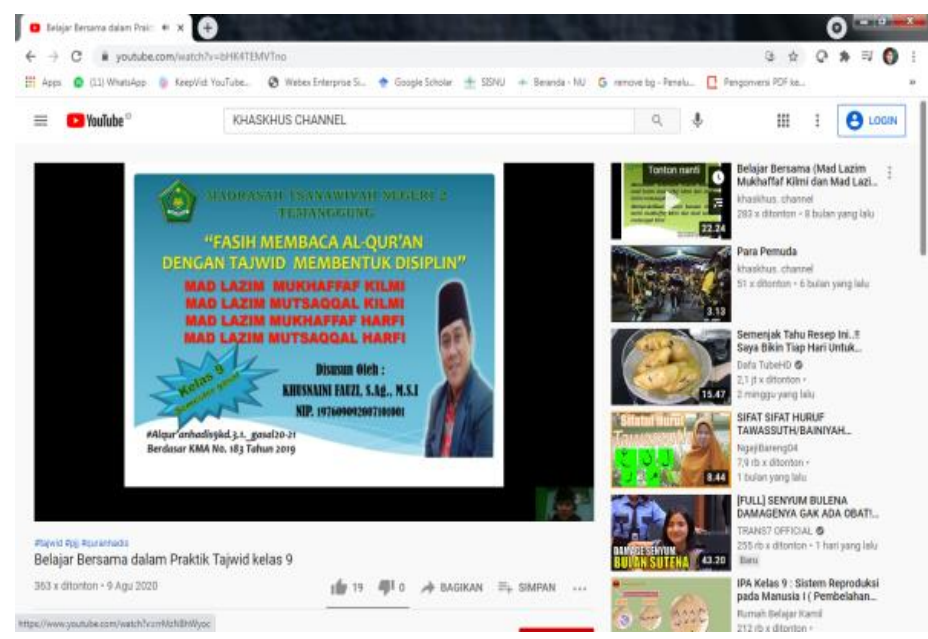

Gambar 5. Materi Tajwid kelas IX yang Di-upload di YouTube 


\section{Google Form}

Google form adalah layanan online dari google untuk membuat formulir online, dan untuk mengumpulkan data, komentar, yang nantinya dapat disusun mengunakan spreadsheet. Fomulir ini untuk membuat soal online, soal tersebut tidak hanya soal pilihan essay, tetapi juga dapat membuat soal pilihan ganda, yang nantinya dapat ditampilkan ke halaman blog untuk kemudian dibagikan kepada siswa dan siswa dapat mengisinya hanya dengan membuka halaman blog tersebut dan mengisi jawaban. Google form merupakan salah satu layanan yang diberikan google untuk kelola pendaftaran acara, jejak pendapat, membuat kuis, dan melakukan kuis secara online. Pada google form terdapat tanggapan survei yang diolah menjadi sebuah grafik lingkaran (Abdin, Saifudin, A., \& Kasman, 2021).

Salah satu manfaat google form dapat digunakan untuk media penilaian dalam pembelajaran, yaitu media pengumpulan tugas baik tugas pengetahuan maupun keterampilan. Siswa mengumpulkan tugas pengetahuan dalam bentuk foto, sedangkan tugas keterampilan dalam bentuk rekam suara dan atau video. Semua tugas tersebut di-upload melalui link google form yang sudah di share oleh guru. Guru dapat mengecek serta mengoreksi tugas dari siswa dengan melihat pada fasilitas response. Fasilitas ini memudahkan guru melihat dan mengoreksi hasil pekerjaan siswa. Selain itu, google form juga digunakan untuk media ulangan harian secara online. Guru dapat memanfaatkan media melalui akun google yang memberikan beberapa fasilitas salah satunya adalah google form. Guru dapat membuat formulir ulangan harian secara online dengan cara membuka akun google kemudian membuka fasilitas di dalamnya, yaitu google drive. Pada google drive ini terdapat satu fasilitas yang bernama google form. Soal atau pertanyaan bisa di buat pada formulir kosong dan atau dari template yang telah disediakan. Guru dapat membuat soal online yang secara otomatis tersimpan pada google drive. Soal bisa berbentuk essay, uraian, menjodohkan atau bahkan pilihan ganda. Soal-soal tersebut dapat di edit secara online. Misalnya, soal pilihan ganda dapat diberi poin atau skor pada masing-masing soal, jawaban yang benar dan salah. Hal ini akan meringankan salah satu tugas pokok guru yang berkaitan dengan penilaian, yaitu mengoreksi hasil pekerjaan siswa.

\section{KESIMPULAN}

Pelaksanaan pembelajaran daring pada masa pandemi Covid-19 memiliki banyak kendala yang dialami oleh guru dan siswa. Solusi alternatifnya adalah selama pembelajaran Al-Qur'an Hadis secara daring guru menggunakan media pembelajaaran yang sesuai dengan karakteristik siswa dan materi, sehingga proses kegiatan belajar mengajar secara online menjadi lebih efektif. Hal ini terkait dengan komunikasi dan interaksi, yaitu guru dapat menyampaikan materi pembelajaran kepada siswa secara efisien. Adapun media pembelajaran yang dapat digunakan guru, diantaranya 1). WhatsApp Group, yaitu media yang bisa digunakan sebagai ruang kelas dan diskusi maya; 2). PowerPoint, yaitu media yang digunakan oleh guru untuk membuat presentasi setiap materi pembelajaran; 3). FastStone Capture, yaitu media yang dapat dimanfaatkan guru sebagai media perekam layar dari materi pembelajaran yang telah dibuat dengan PowerPoint; 4). YouTube, yaitu media online yang bisa digunakan untuk memvisualisasikan materi pembelajaran dengan menarik; dan 5). Google Form, yaitu formulir online yang bisa digunakan untuk media penilaian dalam pembelajaran.

\section{DAFTAR PUSTAKA}

Abdin, Saifuddin, A., \& Kasman. (2021). Pemanfaatan Aplikasi Google Form Berbasis Onlne Sebagai Alat Tes Tertulis Belajar Fisika pada Masa Pandemi Covid-19. Jurnal Penelitian Pendidikan Fisika, 6 (1). https://www.ejournal.bsi.ac.idejurnalindex.phpparadigmaarticleview10092pdf_1

Anshori, Muslich, \& Iswati, S. (2009). Buku Ajar Metodologi Penelitian Kuantitatif. Surabaya: Airlangga University Press.

Arsyad, Azhar. (1997). Media Pengajaran. Jakarta: Raja Grafindo Persada. 
Astini, Ni Komang Suni. (2020). Pemanfaatan Teknologi Informasi dalam Pembelajaran Tingkat Sekolah Dasar pada Masa Pandemi Covid-19. Jurnal Lampuhyang, 11 (2), 1325.

Atsani, K.H. Lalu Gede Muhammad Zainudin. (2020). Trasnformasi Media Pembelajaran pada Masa Pandemi Covid-19. Al-Hikmah: Jurnal Studi Islam, 1 (1), 82-93. http://www.journal.kopertais4.or.idsasamboindex.phpalhikmaharticleview39052796

Azhar, R. (2017). Pengembangan Media Pembelajaran Interaktif Berbasis Microsoft Power Point pada sistem Koordinat Kartesius. Aceh: Akademi Komunitas Negeri Pidie Jaya.

Basri, Hasan. (2015). Paradigma Baru Sistem Pembelajaran. Bandung: CV Pustaka Setia.

Belawati, Tian. (2020). Pembelajaran Online. Tangerang Selatan: Universitas Terbuka.

Fauzi, Khusnaini. (2020). Harokah Barokah (Bergerak Mencapai Keberkahan). Kota Batu: Beta Aksara.

Green, B., \& Hope. (2010). Promoting Clinical Competence Using Social Media. Nurse educator Jurnal, 35 (3), 127-129.

Hamalik, Oemar. (1989). Media Pendidikan. Bandung: Citra Aditya.

Hikmah, S. N., Maskar, S., \& Indonesia, U. T. (2020). Pemanfaatan Aplikasi Microsoft Powerpoint Pada Siswa Smp Kelas VIII Dalam Pembelajaran Koordinar Kartesius. Jurnal Ilmiah Matematika Realistik. 1 (1), 15-19.

Isroqmi, Asnurul. (2020). Pentingnya Penguasaan Beberapa Aplikasi Komputer Bagi Dosen di Pembelajaran daring Berbasis Moodle. Seminar Nasional Pendidikan Program Pascasarjana Universitas PGRI Palembang, 10 Januari 2020.

https://jurnal.univpgri-palembang.ac.idindex.phpProsidingppsarticleviewFile37883466

Maryatun, M. (2015). Pengaruh Penggunaan Media Program Microsoft Powerpoint Terhadap Hasil Belajar Strategi Promosi Pemasaran Mahasiswa Semester 2 Program Studi Pendidikan Ekonomi Universitas Muhammadiyah Metro Tahun Ajaran 2014/2015. Promosi: Jurnal Pendidikan Ekonomi, 3 (1), 1-13.

Munir. (2012). Pembelajaran Jarak Jauh. Bandung: Alfabeta.

Pakpahan, R., \& Fitriyani, Y. (2020). Analisa Pemanfataan Teknologi Informasi dalam Pembelajaran Jarak Jauh di Tengah Pandemi Virus Corona Vovid-19. Jisamar: Jurnal of Information System, Applied, Management, Accounting and Research, 4 (2), 30-36. https://www.journal.stmikjayakarta.ac.idindex.phpjisamararticleview 181144

Prajana, Andika. (2017). Pemanfaatan Aplikasi WhatsApp dalam Media Pembelajaran di UIN Ar-Raniry Banda Aceh. Cyberspace: Jurnal Pendidikan Teknologi Informasi, 1 (2), 122-133. https://www.jurnal.ar-raniry.ac.idindex.phpcyberspacearticleview 1980

Priansa, Donni Juni. (2017). Pengembangan Strategi dan Model Pembelajaran (Inovatif, Kreatif, dan Prestatif dalam Memahami Peserta Didik). Bandung: CV. Pustaka Setia.

Purwanti, L., Widyaningrum, R., \& Melinda, S.A. (2020). Analisis Penggunaan Media Power Point dalam Pembelajaran Jarak Jauh pada Materi Animalia Kelas VIII. JOBE: Journal of Biology Education. 3 (2), 157-166.

Pustikayasa, I Made. (2019). Grup WhatsApp sebagai Media Pembelajaran. Widya Genetri: Jurnal Ilmiah Pendidikan, Agama dan Kebudayaan Hindu. 10 (2), 53-62.

Sari, Luvita. (2020). Upaya Menaikkan Kualitas Pendidikan dengan Pemanfaatan YouTube sebagai Media Ajar pada Masa Pandemi Covid-19. Jurnal Tawadhu, 4 (1), 1081.

Sidiq. Ricu (2019). Pemanfaatan WhatsApp Group dalam Pengimplementasian Nilai-Nilai Karakter Pancasila Pada Era Disrupsi. Jurnal Putri Hijau. Vol. 4 No.2, hal.145-154.

Suryaman, Maman (2015). Penggunaan YouTube sebagai media Pengajaran Bahasa dan Satra Indonesia pada Kurikulum 2013. Jurnal Oktodika, 14 (5), 56-71.

Sutini. (2021). Peranan Orang Tua sebagai Mitra Guru dalam Pembelajaran Daring Selama Masa Pandemi Covid-19. Cendikia : Jurnal Ilmu Pengetahuan, 1 (2), 30.

Wijanarko. (2017). Pemanfaatan Web YouTube dalam Pembelajaran PAI. E-Jurnal Program Pascasarjana Universitas Ganesha, 4. 